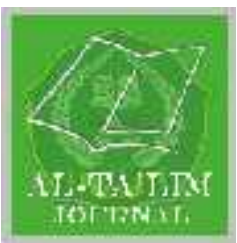

AL-TA'LIM JOURNAL, 23 (3), 2016, (232-240)

(Print ISSN 1410-7546 Online ISSN 2355-7893)

Available online at http://journal.tarbiyahiainib.ac.id/index.php/attalim

\title{
The Effect of Awareness Raising Technique towards Students' Achievement and Reading Interest
}

Received: 02 ${ }^{\text {th }}$ April 2016; Revised: $04^{\text {th }}$ April 2016; Accepted: $10^{\text {th }}$ November 2016

Permalink/DOI: http://dx.doi.org/10.15548/it.v23i3.248

\section{Dwi Settya Mahaputri}

STKIP Abdi Pendidikan Payakumbuh

Email: dwi_settya@yahoo.com

\begin{abstract}
Reading is one of the primary subjects that should be mastered by the students in language learning. Yet, reading activity tends to be a boring activity. To increase the students' interest, the lecturers should be able to stimulate the students' awareness in reading. Therefore, this research is aimed to know the effect of Awareness Raising Technique in teaching reading toward students' achievement and reading interest. This research was experimental research. The population was the second year students of English department of Education Abdi STKIP Payakumbuh. There were three classes. The sample was chosen by cluster sampling. The instruments of this research were reading test and questionnaire. To analyze the data, the researcher used the t-test and ANOVA formula 2x2. After analyzing the data the researcher found (1)students who were taught by using Awareness Raising Technique have better reading achievement than those who were taught by using Presentation Technique, (2) students with high reading interest have better reading achievement than those who were taught by using Presentation Technique, (3) students with high reading interest have better reading achievement than those who were taught by using Presentation Technique, and (4) there is no interaction between techniques and students' reading interest toward students reading achievement at the second year English department of Education Abdi STKIP Payakumbuh.
\end{abstract}

Keywords: Teaching reading, awareness raising technique, reading interest, reading comprehension

How to Cite: Mahaputri, D. (2016). The effect of awareness raising technique towards students' achievement and reading interest. Al-Ta Lim Journal, 23(3). doi:http://dx.doi.org/10.15548/jt.v23i3.248

\section{INTRODUCTION}

Reading becomes the source of knowledge. Through reading, students can comprehend the content of the text and develop their knowledge. Therefore, to obtain it, the students should understand how to interprete the printed and written words because reading is a complex activity that involves both perception and thought. Thus, through reading, students should be able to synthesize, evaluate, and interpret more about subject matter. Due to that opinion, reading helps students in getting and interpreting the reading text.

Reading still becomes the students' most difficult skill in learning English. This 
problem may be caused from several aspects. First, it happpened in the learning process activity. For example, the lecturer applied an uninteresting strategy such as he/she just asked the students to read aloud the entire text and then explained the difficult words found in the text, and finally asked the students to answer the question below the text. This kind of activity made the students reluctant to read and even to understand the text.

On the other side, the students could easily get bored with the material or the text that they should comprehend. This situation could occur because the students lack of vocabulary that made them consult the dictionary often and tried to arrange the meaning of the text in order to be comprehended by them. This activity would make them became tired easily. Finaly, they were not interested in doing the lesson activity especially for reading skill. Besides that, in comprehending the text, the students must know the grammar such as sentence pattern, voice, and tenses, to interpret the idea containing in the text. If they could not understand the text, the idea could be far from the real meaning. As a result of the inability of comprehending the text, the students became passive during the class. This passiveness effected on the students' reading activity. They tended to finish the task quickly without considering whether the answer was correct or not.

Besides that, the other aspects that is also needed in learning is reading interest. Reading interest in relation to Awareness Raising Technique is something necessary for those that are expected to develop students' conscious in learning process. Interest could be defined as a situation arising from the desire to perform reading activities and to achieve a goal. Students' reading interest can be classified into individual interest and situational interest. Individual interest in reading relates to value, knowledge, and positive feelings while situational interest in reading relates to triggered and maintained (Alleman \& Brophy, 2004). With this interest, the students will likely be able to motivate themselves to learn to be independent so it can help them to achieve the maximum learning achievement. In fact, this interest in reading of the students is still undeveloped. They just saw the reading acitvity as the obligation in studying. Therefore, to develop the interest of the students in reading, they should be guided to learn to feel not as an obligation but as a necessity.

Since reading skill is one of compulsory skill taught in English Department of a college. STKIP Abdi Pendidikan Payakumbuh also placed this subject as the compulsory one. Based on the observation conducted to the English Department students' of STKIP Abdi Pendidikan Payakumbuh, it was found that the students' reading achievement was low.

As mentioned above, the factor that makes the students score low might be caused by several factors such as the students did not understand with the text given because of the lackness of vocabulary and the unfamiliarity with the topic. More over, the technique employed by the lecturer less attractive for the students. In this case, the lecturer applied lecturing technique which the students just listened and sometimes pen down some notes if necessary during the lecture. It caused the students felt tired to study reading.

Because of the problems above, it seems that the lecturer have to find a suitable technique to improve the students' skill especially for teaching reading because Harmer (2004) suggests that the teacher should do anything to make the reading activity becoming common handy for the students. Therefore, she also has to find the appropriate technique that encourage the students becomes more interested on reading skill. One of the technique that could help the lecturer and the students is awareness raising technique.

Awarenes raising technique comes from the cognitive learning theories which argue as a prerequisite for the restructuring of 
the learners' mental representation of the language. Thus, the lecturer have to encourage the students to create their personal cognitive knowledge of patterns and rules in language. It means that this technique must meet and maintain the mutual needs and interets of the students involved. Besides, this technique can develop students' cognitive strategies with the consciousness of language learning. Dormer (2013) notes that There are six stages of awareness. The first three awareness stages build up students' motivation to improve, and the second three provide learners with crucial input for change. (Dormer, 2013)

For that reason, this research was conducted by applying Awareness Raising technique in teaching reading to the second year of English Department STKIP abdi Pendidikan Payakumbuh.

In this research, there are four hypotheses, as listed in the following points:

\section{Hypothesis 1}

Awareness Raising technique of teaching reading give significant effect to students' reading achievement at second year English Department of STKIP Abdi Pendidikan Payakumbuh.

\section{Hypothesis 2}

Awareness Raising technique of teaching reading give significant effect toward students' with high interest achievement at second year English Department of STKIP Abdi Pendidikan Payakumbuh.

\section{Hypothesis 3}

Awareness Raising technique of teaching reading give significant effect toward students' with low interest achievement at second year English Department of STKIP Abdi Pendidikan Payakumbuh.

\section{Hypothesis 4}

There is no interaction between Awareness Raising Technique and Students' interest toward students' achievement at second year English Department at STKIP Abdi Pendidikan Payakumbuh.

\section{METHOD}

This research belongs to quasiexperimental research According to Gay, Mills and Airasian (2011) in quasiexperimental research, the researcher tests the hypothesis to find out cause and effect relationship. The researcher manipulated at least one independent variable then controlled other variables and observed the effect of dependent variables. In this research, the researcher investigated the effect of independent variable: Awareness raising technique; the dependent variable namely reading comprehension; and moderate variable is students' reading interest.

The population of this research was students of Second Grade English Department at STKIP Abdi Pendidikan Payakumbuh. The population is spread in three classes (A, B, C); each class consists of 24 students. So, the total population is 72 students. The sample had been chosen by cluster random sampling in choosing the sample. Then, it was found that Class B selected as experimental class which was taught by using Awareness Raising Technique and Class A was selected as control class which was taught by Presentation Technique.

The instruments of this research are reading comprehension test and reading interest questionnaire. The reading comprehension test is used to measure the students' reading achievement, and reading interest questionnaire is used to know about the students' interest of reading. The reading interest questionnaire was given at the beginning of this research, and the reading comprehension test was given at the end of research. The data was analyzed by finding their normality, homogeneity, and hypothesis testing (t-test and ANOVA). 


\section{RESULT AND DISCUSSION}

There are three variables in this research: Awareness Raising Technique, Reading Interest, and Reading Comprehension. And this research has two classes selected; they are experimental class and control class. The experimental class is class B (24 students); are taught by using Awareness Raising Technique, and the control class is class A (24 students); are taught by Presentation Technique. At the end of this research, the researcher gave post test to both classes; reading comprehension test and questionnaire for reading interest. The finding of this research is described as follow:

\section{Reading Interest}

In this research, the researcher divided the students reading interest into two groups; high and low reading interest. In each group there were 6 students in analyzed, as supported by Sudijono (2011) that the number of participants were taken $27 \%$ from each score of reading interest.

Table 1. Students' Reading Interest in Experimental Class and Control Class

\begin{tabular}{lllllll}
\hline \multicolumn{1}{c}{ Class } & $\begin{array}{l}\text { Reading } \\
\text { Interest }\end{array}$ & Mean & Max & Min & SD & Variance \\
\hline Experimental & High & 128.33 & 135 & 123 & 4.27 & 18.27 \\
& Low & 91.50 & 98 & 83 & 6.77 & 45.90 \\
Control & High & 113.17 & 123 & 106 & 7.49 & 56.17 \\
& Low & 78.17 & 88 & 73 & 5.56 & 30.97 \\
\hline
\end{tabular}

From the table above, it can be seen that in experimental class; students' who have high reading interest have the interval 123-135 with mean score 128.33 and the variance was 18.27. And students' who have low reading interest have the interval 83-98 with mean score 91.50 and the variance was 45.50 .

In control class, the students' who have high reading interest have interval 106-123 with mean score 113.17 and the variance was 56.17. And students who have low reading interest have interval 73-88 with mean score 78.17 and the variance was 30.97 .

\section{Reading Comprehension}

The data of students' reading comprehension in this research was taken from reading comprehension test. In experimental process, both classes were given different treatment (experimental class by Awareness Raising Technique and control class by Presentation
Technique). There were 24 students of each class. After gave the reading test, the researcher analyzed the data and got the following statistical result.

Table 2. The Summary of Students' Reading Comprehension

\begin{tabular}{lcllc}
\hline \multicolumn{1}{c}{ Class } & Total & Mean & Variance & SD \\
\hline Experimental & 1859 & 77 & 60.14 & 7.69 \\
Control & 1560 & 65 & 38.65 & 6.26 \\
\hline
\end{tabular}

Based on the table above, it can be concluded that in experimental class, the total score of students was 1859 with the mean score 77 , the variance was 60.14 , and standard deviation was 7.69. While in control class, the total score of students was 1560 with the mean score was 65 , the variance was 38.65, and standard deviation was 6.26.

Furthermore, the students' reading achievement of experimental class and control class also classified based on the frequency distribution that can be seen in the following table: 
Table 3. Frequency Distribution of Students' Reading Achievement

\begin{tabular}{cccccc}
\hline \multicolumn{2}{c}{ Experimental Class } & & \multicolumn{3}{c}{ Control Class } \\
\hline $\begin{array}{c}\text { Interval } \\
\text { Class }\end{array}$ & Frequency & $\%$ & $\begin{array}{c}\text { Interval } \\
\text { Class }\end{array}$ & Frequency & $\%$ \\
\hline $91-96$ & 1 & $4 \%$ & $73-77$ & 4 & $17 \%$ \\
$85-90$ & 3 & $13 \%$ & $68-72$ & 2 & $8 \%$ \\
$79-84$ & 7 & $29 \%$ & $63-67$ & 12 & $50 \%$ \\
$73-78$ & 5 & $21 \%$ & $58-62$ & 2 & $8 \%$ \\
$67-72$ & 8 & $33 \%$ & $53-57$ & 4 & $17 \%$ \\
\hline
\end{tabular}

From the table above, it can be indicated that in experimental class $4 \%$ (1 student) belongs to interval class 91-96, $13 \%$ (3 students) in interval class $85-90$, $29 \%$ (7 students) in interval class $79-84$, $21 \%$ (5 students) belong to interval class 73-78, and $33 \%$ (8 students) in interval class 67-72. In control class, there are $17 \%$ (4 students) belongs to interval class $73-77,8 \%$ (2 students) in interval class $68-72,50 \%$ (12 students) in interval class $63-77,8 \%$ (2 students) belong to interval class $58-62$, and $17 \%$ (4 students) in interval class 53-57.

In this research, the researcher also divided the reading comprehension score of both classes into two groups. They were students with high reading interest and students with low reading interest. The statistical data can be described as follow:

Table 4. Students' Reading Comprehension Score in Experimental Class with High Reading Interest

\begin{tabular}{cccc}
\hline No & $\begin{array}{c}\text { Students' } \\
\text { Code }\end{array}$ & $\begin{array}{c}\text { Reading } \\
\text { Interest }\end{array}$ & $\begin{array}{c}\text { Reading } \\
\text { Comprehension }\end{array}$ \\
\hline 1 & 1 & 135 & 93 \\
2 & 18 & 131 & 70 \\
3 & 9 & 129 & 83 \\
4 & 5 & 126 & 83 \\
5 & 6 & 126 & 83 \\
6 & 7 & 123 & 83 \\
& Total & 770 & 495 \\
& Mean & 128.33 & 82.50 \\
\multicolumn{2}{c}{ Variance } & 18.27 & 53.50 \\
\hline
\end{tabular}

Based on the table above, the students' who have high reading interest in experimental class have the mean score of reading interest was 128.33 and mean score of reading comprehension was 82.50 .
Table 5. Students' Reading Comprehension Score in Experimental Class with Low Reading Interest

\begin{tabular}{cccc}
\hline No & $\begin{array}{c}\text { Students' } \\
\text { Code }\end{array}$ & $\begin{array}{c}\text { Reading } \\
\text { Interest }\end{array}$ & $\begin{array}{c}\text { Reading } \\
\text { Comprehension }\end{array}$ \\
\hline 1 & 4 & 98 & 87 \\
2 & 8 & 96 & 83 \\
3 & 14 & 96 & 73 \\
4 & 24 & 93 & 67 \\
5 & 21 & 83 & 70 \\
6 & 23 & 83 & 67 \\
& Total & 549 & 447 \\
& Mean & 91.50 & 74.50 \\
Variance & 45.90 & 72.70 \\
\hline
\end{tabular}

Based on the table above, the students' who have low reading interest in experimental class have the mean score of reading interest was 91.50 and mean score of reading comprehension was 74.70 .

Table 6. Students' Reading Comprehension Score in Control Class with High Reading Interest

\begin{tabular}{cccc}
\hline No & $\begin{array}{c}\text { Students' } \\
\text { Code }\end{array}$ & $\begin{array}{c}\text { Reading } \\
\text { Interest }\end{array}$ & $\begin{array}{c}\text { Reading } \\
\text { Comprehension }\end{array}$ \\
\hline 1 & 1 & 123 & 77 \\
2 & 2 & 122 & 77 \\
3 & 15 & 112 & 63 \\
4 & 3 & 108 & 73 \\
5 & 6 & 108 & 70 \\
6 & 24 & 106 & 53 \\
& Total & 679 & 413 \\
& Mean & 113.17 & 68.83 \\
Variance & 56.17 & 87.37 \\
\hline
\end{tabular}

Based on the table above, the students' who have high reading interest in control class have the mean score of reading interest was 113.17 and mean score of reading comprehension was 68.83 . 
Table 7. Students' Reading Comprehension Score in Control Class with Low Reading Interest

\begin{tabular}{cccc}
\hline No & $\begin{array}{c}\text { Students' } \\
\text { Code }\end{array}$ & $\begin{array}{c}\text { Reading } \\
\text { Interest }\end{array}$ & $\begin{array}{c}\text { Reading } \\
\text { Comprehension }\end{array}$ \\
\hline 1 & 8 & 88 & 67 \\
2 & 11 & 80 & 67 \\
3 & 4 & 78 & 73 \\
4 & 13 & 77 & 63 \\
5 & 7 & 73 & 67 \\
6 & 23 & 73 & 57 \\
& Total & 469 & 394 \\
& Mean & 78.17 & 65.67 \\
\multicolumn{2}{c}{ Variance } & 30.97 & 28.27 \\
\hline
\end{tabular}

Based on the table above, the students' who have low reading interest in control class have the mean score of reading interest was 78.17 and mean score of reading comprehension was 65.67 .

Based on the result of students' reading achievement from reading test, students' reading interest questionnaire, and statistical analysis of hypothesis testing, it can be discussed as follow:

1. Awareness Raising technique of teaching reading give significant effect to students' reading achievement at second year English Department of STKIP Abdi Pendidikan Payakumbuh

The result of first hypothesis showed that Awareness Raising Technique has significant effect to students' reading achievement than those who were taught by using Presentation Technique. It happened because Awareness Raising Technique was emphasized on helping students' to develop their awareness in comprehending reading passage in order to be able to reading task. As mentioned by Kuhi, Asl, \& Yavar (2013) Awareness Raising can be helpful for students in comprehending of whole text, which is primary aim of teaching reading. It was found that the result from this technique improved students' reading achievement.

Awareness Raising Technique also guides students in creating their knowledge of text that they have to be comprehended. When engaged with reading, the students are believed to go through an active and interactive process, they should have background knowledge about the topic. Because the meaning of the text is not found in reading material itself, but in interaction that take place between reader and the text (Owen, Twist, $\&$ Ford, 2004). Thus, the students were more active to maximize their comprehension through reading activities that involve in Awareness Raising Technique.

Moreover, dealing with the result of this technique which can give better result to students' reading achievement, it is in line with finding of Mashadi \& Haghnevis (2011) that Awareness Raising Technique could lead to a better and more efficient contribution to students' learning aspects. In this research, Awareness Raising Technique gave better contribution on students' reading achievements that being the learning aspect of this research.

It can be concluded that the students who were taught by awareness raising technique have better reading achievement than students who were taught by conventional technique.

2. Awareness Raising technique of teaching reading give significant effect toward students' with high interest achievement at second year English Department of STKIP Abdi Pendidikan Payakumbuh

The result of second hypothesis showed that Awareness Raising Technique had significant effect on students' high reading interest achievement in experimental class than those who were taught by Presentation Technique in control class. Awareness Raising Technique encouraged the students to have more opportunities in understanding and comprehending the text, since there are chances for them to discuss in group. After having discussion, they have to present the result of task in 
front of the class, while other students were invited to give comments the result of each group, whether it was correct or not. If it is wrong, they were all together discuss why it was wrong and what should be the answer. By having discussion, it helped the students to reveal the barriers and gaps that they found while doing the reading tasks. As supported by Thornbury (2005) stated that awareness raising aims at helping students uncover gaps in their knowledge. By this technique, the high interest students' might get the solution of any problem that they in comprehended the reading material. It was different from the control class. The students tended to read the text individually and then answer the questions given without having discussion with others.

Then, the students pay attention more to understand the text. This activity developed sense of competition among them and make them active. It was supported by Hedgcock \& Ferris (2009) mention that active students' are likely to read more if they are interested in the topics of their assigned reading. Besides, they shared more ideas with their group. The students with high reading interest triggers to have curiosity and to know more about text they are reading. It happened since there is also class discussion. In class discussion, the students have to stand up in front of the class to share their ideas. It can be concluded that the students with high reading interest who were taught by Awareness Raising Technique have better reading achievement than those who were taught by conventional technique.

3. Awareness Raising technique of teaching reading give significant effect toward students' with low interest achievement at second year English Department of STKIP Abdi Pendidikan Payakumbuh

The third result of this research indicated that Awareness Raising Technique had significant effect on students' low reading interest achievement in experimental class than those who were taught by Presentation Technique in control class. It could be seen from the score of students' low reading interest that were taught by Awareness Raising Technique was higher than the students' low reading interest who were taught by Presentation Technique. Awareness Raising Technique also helped students with low reading interest to solve problem that the found during the reading activities. The students' awareness was developed through activities of Awareness Raising Technique since the students involve in group discussion. In group work discussion, the students have to participate in discussion to decrease their tense in doing tasks. This is in line with Brown (1994) that group work discussion help students to solve the problem that they found when doing the task. Besides, indirectly it helps the students to understand reading tasks better. It means that the students reading comprehension in experimental class was influenced by group work discussion.

Although the students with low reading interest in experimental class did not pay attention more to the lecturer and material given, they can get higher score than control class because of some factors. This is the result of the students in experimental class had time to discuss with their friends group. Second, when the other students presented the result of their group in class discussion, the others listened a little bit of the explanation. Implicitly, this activity affect to their awareness of the text increased. Third, they did not understand all the meaning of the text, but in fact they still can catch the idea of the text given.

Moreover, these students are helped by the students with high reading interest in group discussion. They are given explanation more by others students related to the material and question that 
being discussed at the time. It is supported by Schunk (2012) when the students do tasks collaboratively with their friends are most effective to increase students' motivation on subject that being discussed. So that, the students with low reading interest in experimental class got help from their friends who have high reading interest.

It was different from the students of low reading interest in control class; they didn't have time to discuss since there are activities of discussion. They tended to be passive during the process of reading; they did not know what to do in finding the information of the text. From the discussion above, it can be concluded that the students with low reading interest who were taught by Awareness Raising Technique have better reading achievement than those who were taught by presentation technique.

4. There is any interaction between Awareness Raising Technique and Students' interest toward students' achievement at second year English Department at STKIP Abdi Pendidikan Payakumbuh

After having analysis of fourth hypothesis, it was found that there was no interaction between both techniques and students' reading interest toward students' reading achievement. The result indicated that reading interest did not give significant effect on students' reading achievement. In addition, the average score of students' reading achievement in experimental class and control class was different. The average score of students in experimental class was higher than in control class. Furthermore, the average score of students' reading achievement with high and low reading interest in experimental class was higher than control class. It indicated that Awareness Raising Technique is more effective than Presentation Technique.
Furthermore, the interaction figure between techniques and reading interest indicated that the lines are not cut one another. There is an interaction between variables; the lines of one factor toward dependent variable are cut one another. Based on this theory, it is concluded that the position of the lines in Figure 5 shows there is no interaction between techniques and reading interest on students reading achievement.

In addition, it can be said that this technique can be used in teaching reading without considering students' reading interest in learning. It can be concluded that interest is not one factor that influences students' reading achievement. Hedgcock and Ferris (2009) state that the purposes of reading comprehension and students reading interest are related but they are not identical, helping students to understand and establish reading purposes is important, but it is distinct pertains to students' reading interest. It means that the students' reading comprehension is related to reading interest, but the technique used in this research did not have relation to students' reading interest.

\section{CONCLUSIONS AND RECOMMENDATION}

From the result of research findings that was done at the second year English Department of STKIP Abdi Pendidikan Payakumbuh, it can be concluded that Awareness Raising Technique in teaching reading gives significant effect to students' reading achievement at the second year English Department of STKIP Abdi Pendidikan Payakumbuh, and also to both students that have high and low reading interest. Furthermore, there is no interaction between teaching techniques (Awareness Raising Technique and Presentation Technique) and students reading interest toward students' reading achievement at the second year English Department of STKIP Abdi Pendidikan Payakumbuh. 
As the explanation from conclusion above, the researcher proposes some suggestions. Awareness Raising Technique was the effective way to improve students' reading comprehension at the second grade of English Department of STKIP Abdi Pendidikan Payakumbuh. Therefore, it was suggested that lecturers can apply this strategy as a variation of teaching reading comprehension. Lecturer can use Awareness Raising Technique in teaching to help students to actuate their reading ability and also it give benefit to the students; they can understand the text by aware of the meaningful text.

\section{REFERENCES}

Alleman, J., \& Brophy, J. (2004). Building a learning community and studying childhood. Social Studies and the Young Learner, 17(2), 16-18.

Brown, H. D. (1994). Teaching by principles: An interactive approach to learning pedagogy. Prentice Hall Regents.

Dormer, J. E. (2013). Improving speaking accuracy through awareness. Journal of Adult Education, 42(1), 16.

Gay, L. R., Mills, G. E., \& Airasian, P. W. (2011). Educational research: Competencies for analysis and applications. Pearson Higher Ed.
Harmer, J. (2004). Language assessment: principle and classroom practice. New York: Longman.

Hedgcock, J., \& Ferris, D. R. (2009). Teaching readers of English: Students, texts, and contexts. Routledge.

Kuhi, D., Asl, M. H., \& Yavari, M. (2013). The Relationship between awareness raising activities and students' proficiency in Reading comprehension of culturally-bound materials. Mediterranean Journal of Social Sciences, 4(3), 515.

Mashhadi, A., \& Haghnevis, M. (2011). The study of structural practice approach vs. awareness-raising approach in teaching verb tenses to EFL students.

Owen, A., Twist, C., \& Ford, P. (2004). Small-sided games: the physiological and technical effect of altering pitch size and player numbers. Insight, 7(2), 50-53.

Schunk, D. H., \& Zimmerman, B. J. (2012). Motivation and self-regulated learning: Theory, research, and applications. Routledge.

Sudijono, A. (2011). Statistik pendidikan. Bandung: Alfabeta.

Thornbury, S. (2005). Beyond the sentence: Introducing discourse analysis. Macmillan Education. 